Caribbean Routes: Ethnographic Experiences, Theoretical Challenges, and the Production of Knowledge

\title{
The construction of identity in haitian indigenism and the post-colonial debate
}

\author{
Frantz Rousseau Déus?
}

'Universidade Estadual de Campinas, Instituto de Filosofia e Ciências Humanas, Campinas/SP, Brasil

\begin{abstract}
This article focuses on three moments in the intellectual elucidation of Haitian identity during the time that Haiti was occupied by the United States, from 1915 to 1934. It analyses the intellectual output of writers of Haitian Indigenism, which emerged during this period of crisis and its political developments. The article makes five main points: first, it presents the emergence of Haitian Indigenism; second, it turns to the first manifestation of Haitian intellectuals against the US occupation, considering the so-called 'writers at the margins of Indigenism; third, it presents the position of authors of the Revue Indigène, particularly of Jean Price-Mars; fourth, it analyses the Revue Les Griots, concentrating on how François Duvalier makes political use of the racial issue. Finally, through these investigations, the article establishes a dialogue with contemporary authors who discuss the construction of identity within post-colonial debate.
\end{abstract}

Key words: Haitian Indigenism; Haitian identity; Post-colonial thought. 


\section{A construção da identidade no indigenismo haitiano e o debate pós-colonial}

\section{Resumo}

Este ensaio se volta para compreender três momentos da formulação intelectual da identidade haitiana quando o Haiti foi ocupado pelos Estados Unidos de 1915 a 1934. Para isso, analiso as produções intelectuais dos escritores do indigenismo haitiano que surgiu neste período de crise e seus desdobramentos políticos. O texto possui cinco pontos: no primeiro, apresento o surgimento do indigenismo haitiano, no segundo, me debruço sobre a primeira manifestação dos intelectuais haitianos contra essa ocupação, olhando para os chamados escritores à margem do indigenismo; no terceiro, apresento o posicionamento dos escritores da Revue Indigène diante da crise haitiana; centrando-me na figura de Jean Price-Mars, no ponto quatro, analiso a Revue Les Griots, olhando para o uso político que François Duvalier faz da questão racial. A partir desse percurso, estabeleço um diálogo com autores contemporâneos que discutem a questão de construção da identidade dentro de um debate pós-colonial.

Palavras-chave: Indigenismo haitiano, identidade haitiana, pensamento pós-colonial. 


\title{
The construction of identity in haitian indigenism and the post-colonial debate
}

\author{
Frantz Rousseau Déus
}

\section{Introduction}

Taking periods of crisis to be moments in which sociological, literary, anthropological and artistic reflections emerge, this article aims to present certain aspects of the social theories produced by intellectuals of Haitian Indigenism, an intellectual and artistic movement that emerged when Haiti was engulfed in a crisis that resulted in the country's invasion by the United States in 1915. Considering that Haiti suffered through slavery, colonization and imperialism, and since it has a long history of struggle against domination, national thinkers have sought to extinguish the scars of these institutions which still endure today. This ratifies the importance of both Haiti and the work of its intellectuals in reflections on the (ex-)colonized and 1 the (ex-)colonizers.

Matters of class, race and religion are at the heart of the internal conflicts that had plagued Haiti since its independence. These matters were manifest in dualisms such as that between nèg anwo and nèg anba (men of the above and men of the below), nwa and milat (Negro and Mulattoes), nèg lavil and nèg andeyò (city dweller and "peasant"); vodou practitioner and Catholics; all of which are relics of Colonialism. Realizing the impact of this colonial heritage, Jean Price-Mars, the main exponent of Haitian Indigenism, appealed to the political, economic and, above all, intellectual elites, to overcome these dualisms which feed into social contradictions. He thus proposed the construction of a Haitian identity that respected difference, which would enable a nonhierarchical solution to the internal conflicts that have historically ravaged the country (Price-Mars, 1919; 1928).

The theoretical depth of this intellectual movement, as well as its contradictions, and how it gave rise to new critiques of coloniality and their subsequent developments, have convinced me that it is time to recover Haitian Indigenism, while also asking how its incorporation into theories of colonialism might benefit postcolonial debates. Much has been written on the Haitian Revolution, but this work often ignores interpretations by local intellectuals, particularly of pre-Negritude ${ }^{1}$ intellectuals (Jonassaint 2013).

By analysing the Works of Indigenist intellectuals of the first half of the $20^{\text {th }}$ Century, this article focuses on three moments of the intellectual formation of Haitian identity. In this way, I stress not only the power games involved in the construction of an identity, but also how the instrumentalization of certain markers of social identity can be dangerous, and why the struggle for identity-formation must thus always be a critical endeavour, as a safeguard against barbarism. By establishing a relation between Haitian Indigenism and the post-colonial debate on colonization and the construction of identity, centred on the figure of Price-Mars (1928) and Stuart Hall (1995 and 2013), I show that Price-Mars's writings may confer on him the status of postcolonialist theorist avant la lettre.

\footnotetext{
1 The complexity of Négritude precludes a consideration of it in this article. I would just note that it is one of the Afro-French-Caribbean literary movements that emerged at the start if the 1930s. For a discussion of this movement, see Bonjour et adieu à la Négritude, published in 1989 by the Haitian scholar René Depestre.
} 


\section{The emergence of Haitian Indigenism}

Haitian Indigenism (indigénisme haitien), or the Indigenist movement, was a humanist movement with a sociocultural, anthropological and political character that took shape through the invasion of Haiti by the United States of America in 1915. The movement was a reaction to North American imperialism, against physical, moral, intellectual and spiritual colonization, and against racism, and, more specifically, colonial racism (Charles, 1984; Guerrier, 2008).

According to Jean Pierre (2009: 77), the creation of the Revue Indigène in 1927 is a key moment for this movement. One year later, with the publication of Jean Price-Mars's Ainsi parlal'oncle, the movement underwent a revolution ${ }^{2}$. The importance of the works of Price-Mars have led him to be considered the main theoretician of this movement (Charles, 1984; Fardin, 2009).

I should note that one of the main questions faced by studies of Haitian intellectual history consists in determining when Haitian Indigenism ends ${ }^{3}$. I will weave some considerations on this movement, shining a spotlight on the generation known as the "writers of the Revue Indigène", exploring the question of Haitian identity as it appears in their writings through their proposal for a rupture in the conception of what this Haitian identity might consist of ${ }^{4}$.

Although my analysis emphasizes authors of the Revue Indigène, I will also consider intellectuals who had taken a stand against the United States Occupation prior to the creation of the Revue Indigène. My aim is to understand how Haitian identity was represented and how the Revue Indigène creates a rupture, particularly after publishing Jean Price-Mars in 1928. I will also deal with how Indigenism was interpreted by the authors of the Revue Les Griots, centred on the figure of François Duvalier, who later, on coming to power, instrumentalized the racial issue to consolidate his control over the country.

Realizing the dangers of the marginalization of the Haitian people by the Americans, and without turning their backs on the French legacy, the literature produced during and after this period by exponents of the Revue Indigène endeavoured to construct a Haitian identity founded on the valuation of culture, local values and African roots, through social education (Price-Mars 1928).

\footnotetext{
2 Price-Mars was a Haitian politician, diplomat and writer. He was a congressman from 1905 to 1908, before occupying diplomatic posts in Paris, Berlin, Washington and Santo Domingo. He was a senator from 1930 to 1935, and a defeated presidential candidate in 1930 . In 1941 he founded the Bureau d'Ethnologie d'Haiti and the Institut d'Ethnologie, during a period in which the Catholic Church was waging an anti-superstition campaign (1939-1942). His commitment to the monde noir brought him international fame. With the publication of Ainsi parla l'Once, the writer of the génération de la honte, the Haitian 'generation of shame', came to demonstrate him a measure of respect, calling him Oncle, 'uncle'. In 1956, his eightieth year, he was honoured by Haitian intellectuals and the biggest names in African studies. In that same year, Price-Mars was unanimously elected as the first president of Society of African Culture. He was considered for the Nobel Prize in 1959, and gained a number of prizes and honorary titles. By the time of his death in 1969, Price-Mars had published fifteen essays and numerous articles.

3 Fardin (2009) is one of the rare critics to classify Indigenism in four stages. The first stage is called "the writers at the margins of the Indigenist Movement", corresponding to the period from the invasion of Haiti by the United States in 1915 to the creation of the Revue Indigène in 1927. This period is characterized by a steep rise in national sentiment, and activism. The second phase extends from 1927 to 1934, the year in which the occupation of Haiti formally ended. The third phase, called Revue Les Griots begins with the creation of the eponymous Journal in 1930, and ends in 1940. Finally, the fourth phased is called "rebellious Afro-Indigenists", spanning the period from 1940 to 1961 . Fardin's classification is questionable, most of all because there is little reason to see the emergence of the Revue Les Griots as a phase of the movement - the ideals promoted by its representatives, particularly François Duvalier, do not square of those of Price-Mars's Indigenism. Although he based himself on Price-Mars's theories of Inidgenism, Duvalier disfigured Price-Mars's ideas to construct a theory of racial essentialism founded on obscurantism that came to be known as Noirisme (Jean 2018: 62).

4 The monthly Revue Indigène was launched in 1927, with the stated aim of publishing the work of Indigenist intellectuals. Only six issues were released, the last one dated February 1928. However, despite its short publication run, the ideas promoted by its contributors had an impact of Haitian thought, and influenced generations of writers extending into the present.
} 
Identity, class, religion and "race" are venerable issues in Haitian society, but they gained new contours with the United States Occupation. Social contradictions were manifest soon after Haitian independences. The emergence of the Indigenist Movement, however, opened new avenues for a critique of the nature of these contradictions during that time.

Indigenist analyses reveals how the country's past extends into the present, since the legacies of slavery and colonization had destroyed, and continued to destroy, social relations in Haiti. They left Haiti in a state of permanent conflict, marginalizing the majority of the Haitian population and reinforcing negative stereotypes of their religious beliefs, cultural practices of African origin, and socioeconomic conditions.

Before Indigenism, there were already Haitian intellectuals who sought to defend Haiti while contributing to a positive image of the Black race. A study of Haitian Indigenism thus leads to an analysis of the social representations produced and conveyed by intellectuals. The works of Anténor Firmin ${ }^{6}$ (1885) and Hannibal Price $^{\gamma}(1898)$ were sources of inspiration for many of the Indigenist intellectuals, since they already defended a positive image of Black people at the end of the $19^{\text {th }}$ Century, seeking to (re-)insert them in the modern, postslavery world, reclaiming the common humanity of all peoples, and fighting for racial equality.

In the same vein, during the second decade of the $20^{\text {th }}$ Century, with the United States Occupation of Haiti (1915-1934), Jean Price-Mars (1919, 1928, 1929), Dantès Louis Bellegarde (1928. 1929, 1937), Stephen Alexis (1933), and others, acted vigorously not only to fight against North American cultural imposition and to construct a positive image of Haiti, but also to construct a Haitian identity that could overcome its internal dualisms.

As I have already noted, internal conflicts of various sorts emerged after independence, leading to the assassination of Jean Jacques Dessalines, the first president of the Black Republic. A chaotic situation began to develop in Haiti, with the persistence of contradictions, conflicts over political power by various social actors, attempts to maintain privileges, to accumulate wealth, and finally with imperialist interventions during the early $2 \mathrm{O}^{\text {th }}$ Century. During this time, the country went through a crisis of chronic political instability. Between 1911 and 1915, Haiti had six presidents, four of whom only relinquished power in 1915 (Fardin, 2009).

\footnotetext{
5 Haiti gained Independence in 1804 through a revolution carried out by an alliance of freemen (Mullatoes) and enslaved people (Blacks) (Hector and Hurbon 2009). After independence, the Mullatoes claimed the wealth of the former colonizers as inheritance, believing themselves to be their children. At the same time, the country came to be governed by a former Black slave, Jean Jacques Dessalines. Although it is impossible to deny a racial element in the political conflicts that culminated in Dessalines's assassination, the authoritarian character of his government and the dissatisfaction of Haitians of all social classes with a set of political-administrative measures announced by Dessalines led to revolt against his government, and to his assassination on the 17th of October 1806. Consequently, from 1806 to 1821 , the country was divided into two parts: the North, governed by Henry Christophe (1767-1820), known as King Henry, and the South governed by Alexandre Pétion (1770-1818). There is a tendency to sum up the existing social contradictions as a dualism of Black versus Mulatto. Without ignoring that this was a dimension of these contradictions, I believe that they are more complex than this. According to Trouillot (1990: 109), the dominant classes were not exclusively made up of lighter-skinned people; and not all such individuals were a part of this class. In this way, Trouillot (1990: 127) allows that the matter of skin colour is always present within the Haitian state, without, however, emerging as an all-out colour war in public disputes. The political-ideological debates of the second half of the 19th Century between the liberals, pouvoir au plus capables ('power to the most capable'), and the nationalists, pouvoir au plus grand nombres ('power to the most numerous'), make this dimension explicit. In Trouillot's formulation, both the categories 'most capable' and 'most numerous' continued to function as codes of etiquette behind which everyone could perceive the question of skin colour without framing it explicitly.

6 Joseph Anténor Firmin was a journalist, lawyer and an ardent defender of racial quality. He was born into a modest Family in Cap-Haïtien in 1850 and died in 1911. He created a journal in his native town, called Le Messager. In 1867 he ran for congress, but did not get elected. Firmin was socially, politically and intellectually engaged and active. He was exiled around 1883, went to São Tomé and later to France, where he met the Haitian intellectual Louis Joseph Janvier and became a member of the Société d'Anthropologie of Paris in 1884. This was a decisive moment in Firmin's life, which put him in contact with the predominant conceptions of race. As a result, in 1885 he published De l'égalité des races humaines:anthropologie positive.

7 Hannibal Price was born in Jacmel, in southeast Haiti, in 1841. He was a diplomat and a lawayer. Price was voted president of the Haitian Congress in 1876. He els Foreign Minister during the 189os, and the Haitian ambassador to Washington, where he died in 1893. He was a member of the Pan-African Congress. Hannibal Price authored a number of works, among which the most famous is De la réhabilitation de la race noire par la République d'Haïti (posthumous book, published in 1891, in which he provided a critical reply to the British author Spencer St. John who had published, in 1886, Haïti ou la république noire).
} 
Seizing this internal political instability, the government of the United States organized the military invasion of Haiti on the afternoon of the $27^{\text {th }}$ of July, 1915. This was a painful period in Haiti's history as an independent country, when it became a veritable colony of the United States, a condition that violated the Haitian Constitution (Bellegarde, 1937). Faced with this situation, members of the Indigenist Movement not only fought against the occupation, they also proposed the construction of a national identity founded on popular culture and local values. Thus, Price-Mars $(1919,1928,1929)$ attacked a set of prejudices and taboos that predominated in Haitian society, condemning what he called collective Bovarysme - Haitian shame of their African heritage and the association of vodou with witchcraft and superstition.

In opposition to what Jean Price-Mars (1928) called collective Bovarysme, a disdain for one's own culture and values in favour of those coming from the centre (hegemonic western countries), he proposes the motto soyons nous même le plus complètement possible (let us be ourselves as completely as possible). Through his position, Price-Mars argued that Haitians, and, more generally, Blacks, must stop being what colonial (particularly French) discourse makes of them, so that they may not only establish their own discourse, but also reclaim their place as subjects that share in universal characteristics. He was thus criticizing a western humanism that infantilizes Africans and Blacks, denying them an outright humanity. As Fanon (2008 [1952]) later realized and criticized, in western culture "to be human is to be white". This presupposes that only white Europeans are gifted with perfection.

Judith Charles (1984: 51), a scholar of Indigenism, observes that the Unites States Occupation was a crucial period for Haitian social thought. The intellectuals of the time defined Haitian Indigenism as the search for an identity that emerged from anti-imperialist nationalism in the context of the United States Occupation. Publishing studies such as La vocation de l'élite (1919), and Ainsi parla l'oncle: essais d'ethnographie (1928), PriceMars demonstrates the need to turn to popular culture, not just to resist the Occupation, but also to contrast a Haitian identity that takes differences into account. According to Corbisier (1967: 13), when those who are colonized stand up against the assimilation of the values of the colonizer, and reclaims her identity, everything that ashamed her, everything that she saw as a source of humiliation - the beliefs, values and customs everything that fed into the inferiority complex of the colonized is assumed and rendered positive. The very name of the Revue Indigène makes this dimension evident during the United States Occupation ${ }^{8}$.

For a long time in Haiti, indigène had been considered a great insult. In light of this, Normil G. Sylvain, who wrote in the first issue of the Journal, claims: "comme on fait une manière d'insulte du mot indigène nous le revendiquons comme le titre, le point de vue de l'indigène" (Since they make the word indigenous an insult, we reclaim it as a title, the point of view of the indigenous) (Sylvain, 1927: 10).

The writings of Price-Mars thus paved the way not only for a positive evaluation of the history of Africa, of vodou religion and African myths of origin, but also for a positive view of popular culture and of those who were excluded, who lived in the hinterlands. At the same time, it questioned the values that were imported from the hegemonic West, particularly from the United States and France. Charles stresses that:

Indigenism can designate what is profoundly Haitian, Indigenism thus becoming synonymous with Haitianism, reflected in their literature, to a way of thinking and feeling that is proper to Haitians, their customs, their values, their beliefs, their cultural life, in brief, everything that is intrinsic to them. (Charles 1984: 7).

8 According to Jean (2018) the term indigène comes from the Latin indigena: indi or endu (in the interior, from the country) and gena (born, gestated). He notes that the term indigène can be used in two senses: as an adjective; and as a noun. Indigène as a noun refers to those who are native to a country or region, and also to those who have always inhabited a country; and it likewise refers to plants, animals and produce (indigenous plants, indigenous animals, indigenous produce) (DAF, 1932 apud Jean, 2018). 
Furthermore, Price-Mars expounds on the responsibilities and duties of the elites in the context of the problems that Haiti was facing during that period. In the same vein, Stephen Alexis (1933: 57), in his novel Le nègre masque, tries to find a non-hierarchical way out, favouring the union of urban elites and peasants, Blacks and Mulattoes, in a common struggle against the United States Occupation.

\subsection{Writers at the margins of Indigenism and the Haitian crisis}

Intellectuals such as Dantès Bellegarde and Léon Laleau, who spoke out against the Occupation from the start - that is, before the emergence of the Revue Indigène - are called writes "at the margins of Indigenism" (Fardin 2009; Charles 1984). By assuming a critical posture to the occupation, Bellegarde displayed a strong commitment to French culture in opposition to the culture of the United States. In Pour une Haiti heureuse, the author (Bellegarde, 1928; 1929) reiterates the intimate relations between Haiti and France, stressing that Haitians belonged to Africa by blood and to France by spirit. Bellegarde (1928: 76) writes that "the French blood is mixed in our veins with African blood, and in our lips with the sweet parler (speech) of France". Renouncing France would thus be equivalent to renouncing half of ourselves (Haitians). He stresses that Haiti was an intellectual province of France, and that there is nothing in this position that diminishes the Haitian personality (Bellegarde, 1929: 406). Bellegarde, as well as other authors active prior to the establishment of the Revue Indigène, perceived that resistance and struggle against this occupation demanded a conscience of what it means to be Haitian.

Although Bellegarde spoke out against the United States Occupation of Haiti, Price-Mars differs from him on what exactly this identity consists of. Later, however, according to Fardin (2009: 31), following Price-Mars's recommendation, Bellegarde accepted the importance of Haitian folklore, arguing that its study was required to re-establish the Haitian person. Thus, Bellegarde (1937) points out, in order for the Haitian people to de-alienate, it was first necessary for them to self-conquer - that is, to recognize and reconcile with their African roots.

According to the literary critic Judith Charles, writers, particularly those novelists at the margins of Indigenism, spoke out against white-mania and Black-phobia, also writing against Africaphilia. Their stance was in favour of an indigenous literature. Their writings reflect "deplorable spectacles that Haitian society offers and the chasm in which it continues to fall" (Charles 1984: 53). The novel Le choc by Léon Laleau, and other novels published in that period, sought to expose the main causes that provoked the United States Occupation, condemning the existing tensions between the elite and the masses, between cultures of African and French origin (Charles 1984).

According to Fardin (2009), the writers at the margins of Indigenism were infatuated with French culture, which was their source of inspiration, However, they recognized the existence of a national culture, precisely because they were national writers. According to Fardin (2009: 33), the difference between the writers at the margins of Indigenism (1915-1927) and those of the Revue Indigène (1927-1934) is that the former valued their French origins and did not want to renounce it. In contrast, the intellectuals of the Revue Indigène struggled to (re) construct Haitian identity, emphasizing African elements which had been unfairly despised and discriminated against. My main focus is the Revue Indigène, because it is in its pages that the debate on the construction of Haitian identity retains a contemporary resonance. 


\subsection{Writers of the Revue Indigène during the Haitian crisis}

As one of the main thinkers of Haitian Indigenism, Jean Price-Mars criticized the behaviour of the Haitian elite, making evident the grave problems that society was facing. He appealed to the elites to clarify and conduct with dignity the spirit of the population (Price-Mars, 1919: 36). This problem was expressed in the way that Haitians conceived of themselves in this society at that time. Price-Mars (1928) drew the elite's attention to the fact that "the Haitian" is not un fraçais coloré, a coloured Frenchman, as many in the society believed. They are Haitians tout court, people born in specific socio-historical conditions, who, like all human groupings, internalized in their souls a sociopsychological complex which was responsible for their way of being.

Price-Mars lamented that everything that was indigene (language, religion, customs, sentiments, beliefs) was deemed suspicious and in bad taste in the eyes of the Haitian elite and their nostalgia for a lost homeland. He stresses that the word nègre (Negro) was usually used in a pejorative sense. Similarly, the word africain (African) in Haiti was the most humiliating qualification that an individual could receive. However, this rejection of an African origin was not exclusive to Haiti. Regarding Martinique, Fanon (2008 [1952]) wrote that, "we knew in the past and know still today people who are ashamed to be taken for a Senegalese". Price-Mars (1928: 10) notes that a Haitian would rather be similar to an Eskimo than to an African. On Price-Mars's notion of collective Bovarysme, Parise writes:

The denial of Haitian culture, such as the damning of the Vodu religion and the prohibition of the Crioulo tongue in schools, produced a country with two representations: French and Crioulo, European and African, Catholic and Vodu practitioner, lettered and oral (illiterate), considering that, even today, the majority of the Haitian population is illiterate, spoken and written French being restricted to a minority (Parise 2014: 75).

This aversion to the majority of the Haitian population is linked to how Africa and post-slavery Haiti were represented in European history. In 1866, Spencer St.-John published Haiti ou republique noire, in which he noted that "the Haitian population tends to lower itself to the state of African tribes, despite the neighbourhood of civilized countries around Haiti" (St.-John 1886: VIII). He further proceeds observing that "the peasant mass of Haitians who live in rural lands, who rarely have contact with civilized peoples, and who have few priests to teach them the true religion, have no authority that can prevent them from participating in barbaric ceremonies of witchcraft"9. Despite Spencer's work having been heavily criticized by Haitian authors, such as Hannibal Price in 1898 , these criticisms were not enough to dispel the prejudice against peasants and vodou religion.

In 1912 there was a second "anti-superstition campaign" 10 in Haiti, led by the Catholic Church. This campaign involved a repressive attack, spearheaded by the clergy, to combat all religious visions contrary to the Catholic doctrine. Vodou was considered to be a set of superstitions, witchcraft practices, and, therefore, an obstacle to civilization (Clorméus 2012: 154). As Nicholls (1975: 666) reports, this campaign was strongly supported by the State, which, at the time, not only recognized the Catholic religion as the religion of the State, but also distributed presidential pamphlets encouraging the repression of the vodou religion, exterminating practitioners and ougan (vodou priests).

\footnotetext{
9 Spencer referred to 'vodou', a religion of African origin that was only recognized as a religion in 2003, by presidential decree, signed by president Jean Bertrand Aristide, who was a former priest.

10 According to Clorméus (2012), the first anti-superstition campaign formally began with the Accord of the 28th of March 186o, when the Catholic clergy was responsible for officially "civilizing” and "moralizing” the Haitian masses through the Gospel. Clorméus (2012: 105, author's emphasis) notes that: "In a report presented to Ministry of Cults in 1861, Father Pascal proposes a set of means for intervention so as to moralize and civilize the Haitian Republic, wishing to abolish the vodou religion, to put an end to the diabolical reunions that hindered the spread of the Gospel and the tranquility of the country. It is the source of conspiracies, and in it the cult of idolatry is still an honour".
} 
In these pamphlets, President Cincinnatus Leconte (1911-1912) drew the attention of the peasants to the harsh penalties for those who practiced vodou, according to the penal code of the time. According to Clorméus (2012), this measure was welcomed by the Haitian elite and many intellectuals at the time, since they saw the prohibition of vodou as a path toward civilization. For these intellectuals, vodou had a negative impact on images of Haiti abroad.

It is in this key that Price-Mars will criticize Haitian historians who dogmatically reproduced these ideas. According to Price-Mars, they become obsessed with false opinions that the Europeans had of African religions, or religions of African origin:

For all authors of General History, for geographers, for travellers, explorers, the first essayists of the history of religions, Africa is the classic land of fetishism. However, it is astounding that, regarding other Blacks, we repeat, based on our Catholic faith, "The Blacks of Africa are witches"; and then, consequently, that those of Santo Domingo are also followers of witchcraft" (Price-Mars, 1929: 91-92).

The author considers that this view of Africa is too superficial and prejudicial. To deconstruct these prejudices, Price-Mars investigated the popular culture, beliefs, and religion of Haiti, that the old enslaved people conserved after four centuries of being transplanted from Africa to the Caribbean. In his view, a consistent investigation of Haitian culture should also take Africa into account:

To study African beliefs is to raise ourselves to the height so as to apprehend the most apparent expression of this imponderable that is the Black soul, and furthermore, to follow the modalities of its eventual transformations, its unconscious survivals in this colossal ethnic transplantation which was Black slavery in the Americas (Price-Mars, 1928: 92).

Jean Price-Mars was convinced that the de-alienation of the Haitian people demanded a new approach, which should defend the "Black race", Haitian and African culture, and, at the same time, to question the hegemony of Western legacies. In Une étape de la formation haitienne, he underscores that, during the United States Occupation of Haiti, "there was not an intellectual crisis, but a moral crisis. Which is defined by the collapse of the character of the Haitian as a function of the United States Occupation" (Price-Mars 1929: 80). Stephen Alexis (1933) raises a similar point. One of the characters in his novel, Le nègre masqué, was a false Negro, who hid her a face behind a mask. This mask, according to the novelist, resulted from her upbringing and the type of society of which she was a part.

Analysing Stephen Alexis's novel, Judith Charles stresses that the novelist was aware that, for Haitians to attain the authenticity of their being, they first of all needed to accept themselves. However, the Haitian elite, rejecting a set of values and arbitrarily electing another set, always remained strangers to themselves (Charles 1984: 72). Like Price-Mars, Alexis waged a struggle for the spiritual liberation of Haitians. Following the steps of the Uncle, the symbolic character used by Price-Mars in his classic book Ainsi parla l'oncle, it was through maternal Africa that the Indgenists of the Revue Indigène (re)elaborated their identity, standing against cultural assimilation by western values. With the help of Black ethnic groups, national conscience was therefore taken to be an antidote to white racism. And, accepting Blackness à part entire, the Black ideology will be a counterpoint to, and surpass, the dominant white ideology, whether it be North American or from elsewhere (Charles 1984: 77).

In the construction of a Haitian identity which takes into account the analyses of the thinkers of the Revue Indigène, the popular beliefs of peasants occupy a central role. For many of the Indigenists associated with the Revue Indigène, all popular beliefs are conceived to be phenomena than encompass the psychological and social character of a people. Looking for elements that are amenable to a construction of the Haitian identity, Price-Mars (1928) studies Haitian folklore, following the perspective of William J. Thorns. However, Price-Mars 
sustains that, with the development of civilized life, old mannerisms, traditional customs and ceremonies were rejected by the dominant class, and transformed into superstition when conserved by the popular classes. For him, folklore encompasses all of the "culture" of a people that has not been employed in official religion or in the history of its civilization. We can perceive as well that the Indigenism, as a national movement also uses, at its base, European notions. That is, it is a nationalism that also produces itself by selecting European theories, and not only through their abandonment or negation.

In different writings, Price-Mars weaves positive considerations of folklore. In Étape de l'évolution haïtienne (1929: 85) he defines "folklore as the science of tradition [...] which provides an aide for other sciences and for the history of religion". In Formation ethnique, folk-lore et culture du peuple haitien (1956:42), he defines it as "the sum of beliefs, superstitions, legends, stories, songs, divinations and customs upon which the primitive life of a people rests, and they constitute the scaffolds of a 'culture"'.

Mindful of the importance of the folklore of a people, Price-Mars also investigates the customs and beliefs of some countries in Africa in a comparative manner, tracing the history of the Sudan, ancient Dahomey, Congo, and so forth, Price-Mars identifies similarities between African and Haitian folklores. Considering religion, mythology, beliefs, and other practices, he highlights the existence of a centre of spiritual representations in Dahomey called Vodoun. However, under other names, in other parts of Africa, there were also similar beliefs which shared a base with Haitian vodou. Price-Mars (1928: 56) stresses that "Haitian vodou is a syncretism of beliefs, a compromise between the animism of Dahomey, the Congo, the Sudan, and others". He notes that Haitian vodou, during its formation, was also influenced by Christianity, particularly by Catholicism.

Colonial prejudices, as we have already observed, weighed increasingly heavily on Africa and on Blacks in general. Against this, Price-Mars (1928) criticized prejudiced and arbitrary views that considered Black Africa to be a place of witchcraft. In contrast, he showed how prejudice makes it difficult to see anything other than superstition in the religious sentiments of Black people, and that the manifestation of their beliefs was not seen to be an act of devotion. Thus those faithful to this religion were accused of all manner of evils, including the immolation of human victims in vodou ceremonies. This view was responsible for much of the violence inflicted on practitioners of this religion. Soon after Independence, in 1804, a number of repressive acts were carried out against vodou, led by the Catholic Church. The Haitian elite took this idea on board and continued to reproduce this very same representation, until it became generalized throughout the country. Price-Mars (1928: 161) lamented this fact:

We certainly do not know of anything more trivial than the belief which makes vodou into a cult of anthropophagy. What is worst is that this is almost the generalized Haitian belief in supernatural disease. These predispositions of the spirit inevitably lead one to consider death to be the result of witchcraft, thus leading individuals to accuse the vodouisant (practitioner of vodou) to be a witch. This is the potency that the poor minds of the people of this country dispose in what pertains to the vodouisant. Based on these prejudices it is not surprising that foreign journalists who come to this country publish in their newspapers sensationalist chronicles of Haitian barbarism concerning human sacrifices that they never saw, but gathered material for their narratives, which lack both sense and credibility, merely from the naïve beliefs of the country. [...] For about a year, perhaps months, we have been hearing details of a very strange story about people who have been dead for some time and who were found to be alive, in this or that part of the country.

This prejudiced representation was as diffuse among the Haitian elite as among the people, projecting a negative social image, causing the elite, above all, to increasingly ignore and to distance themselves from their African roots. 
According to Price-Mars, Portuguese seamen, in their initial contacts with Blacks in West Africa, noticed that the population seemed to adore material objects. They called the spiritual manifestation of Africans a "cult of the fetish", culto de feitiço. The Portuguese word feitiço derives from the Latin factitus, meaning artificial. Criticizing the interpretation of Portuguese seamen, Price-Mars notes that they only observed a part of the phenomenon, from which they intended to derive everything related to the religiosity and spirituality of Africans. According to him, fetishism is not a religion, and African Blacks do not therefore worship material objects. What they worship is the spirit that they believe to be incarnated in some forms of matter, particularly in great cosmic forces: Sea, Land, Rivers, Forests, etc. Price-Mars (1929: 92) concludes that "animism is the universal religion of Africa".

Refuting the fetishism attributed to African religions, Price-Mars (1929: 96) stresses that, throughout Africa, even the most primitive people believe in an Être tout puissant et unique (all-powerful and unique Being). He compares the moral precepts that exist in Africa with those that Yahweh (God) passed on to Moses on Mount Sinai, claiming that there is no difference between the types of prohibition that guide the lives of believers. That is, both in Christianity and African religions, the individual is forbidden from stealing, killing, committing acts of adultery, etc. The authors of the Revue Indigène are central because they attempt to denaturalize the prejudices that weigh on the religion of Black people and, at the same time, draw the attention of Haitian intellectuals that did not want to recognize the role of African values and culture in the construction of Haitian identity.

Following the recommendations of Price-Mars, Bellegarde (1937) draws attention to the conditions in which enslaved people lived in Santo Domingo, underscoring that they worked for 18-hour shifts, in the worst conditions, and did not have the right to organize or even to gather, since they were not treated as full human beings. As stated in article 3 of Jean-Baptiste Colbert's Code Noir of 1685, during slavery:

We Forbid any public exercise of religion that is not Catholic, Apostolic and Roman. That offenders are to be punished as rebels and insurgents by our command. We will forbid all groups to this end, we must declare them conventicles, illegal, and seditious, subject to the same punishments that will be handed out, even against masters who permit it, and who will suffer in relation to their slaves (Colbert, 1685, Art.3).

According to Price-Mars, all religion requires a means of manifestation - a service, congregation, devotion. However, no other religious and cultural manifestation was so watched over as that of the former slaves. As the above passage stresses, the former slaves of Santo Domingo were forced to submit their faith to the Roman Catholic religion, against their desires. This is made explicit in article 2 of the Code Noir, which states that "All slaves in our islands will be baptized and educated by the Roman Catholic Apostolic Church".

The prohibitions and repressions forced Blacks to live in deep dissimulation. But they did not abandon their beliefs. At night, while the masters were asleep, slaves held great meditations. At that moment, they rejected their défroque of resignation and recovered their true personality, praying to their true God, who did not spill the blood of enslaved people, and who took no pleasure in the suffering of Blacks (Price-Mars 1929: 100).

As I see it, in the perspectives of Price-Mars and Bellegarde, the context in which those who were enslaved lived had an influence on how they carried out their rites. The fact that they were forbidden from manifesting their faith forced them to use the night, while the masters were sleeping, to pray, meditate, etc. This will ultimately confer upon it the character of a hidden religion - but the context in which it was practiced is needed to explain this dimension. These considerations were not taken into account by historians that studied the vodou religion after slavery, and thus many of them attributed to it a diabolical character, an image which persists today.

Through his considerations of vodou, Price-Mars reveals that it is a religion like any other religion, with its own theology, a system of representation through which African ancestors originally explained natural phenomena. He argues that: 
Vodou is a religion, because all of its practitioners believe in the existence of spiritual beings that live somewhere in the universe in close ties with humans, and who dominate their activities. [...] Vodou is a religion because the worship of its gods requires a hierarchical sacerdotal body, a society of faithful, temples, altars, ceremonies, and, finally, an oral tradition which, no doubt, has not reached our days without any alteration, but through the deeds of those who transmitted the essential parts of this worship. [...]. Vodou is a religion because, through a meshwork of legends and the corruption of fables, it can unravel a theology, a system of representation through which our African ancestors originally explained natural phenomena, which remains latent in the anarchic beliefs underlying the hybrid Catholicism of our popular masses (Price-Mars 1928: 32)

After presenting a positive view of vodou, many intellectuals revealed themselves to be favourable to Price-Mars's interpretation. They emphasized his great contribution to elevate vodou to the level of a religion. Lewis Ampidu Clorméus (2012), who researches intellectual and religious discourse on vodou, claims that Price-Mars's greatest achievement was to have developed a scientific approach to vodou that did not offend the Haitian elites. Until the end of the 1920s, many literary writings with scientific pretensions condemned vodou in Haiti, generally describing it as a diabolical feast. Byron (2014), another student of Price-Mars's writings, emphasizes that the great merit of the writings of Price-Mars, particularly Ainsi parla l'oncle, lay in his contribution toward dispelling the notion of superstition attributed to the vodou religion, so that it gradually emerged as a marker of Haitian identity. Byron (2014) insists that Price-Mars's goal of constructing a Haitian identity did not aim to promote a Haitian cultural specificity as ontology, but rather to treat it as a process of the political and cultural integration of the social categories that had been excluded from the Haitian nation.

The United States Occupation was the trigger that enabled Haitians to (re)think their ways of acting in the world. As Souffrant (1991: 20) highlights, the Occupation acted as a starting point for Haitian intellectual thought, a review of values and a moment for questioning the existing political and social order. This moment of crisis was decisive for making Indigenist intellectuals conscious of the need to construct a Haitian identity anchored in plurality. The elite, however, was not (and is still not) disposed to forego its privileges. After the end of slavery, this elite claimed the place of the colonizers, trying to reproduce the latter's domination without the need for an occupation, acting in such a way as to prevent the masses from attaining a decent standard of living. To overcome these problems, Price-Mars (1919:36) proposed a social education which is:

A discipline to which every individual should submit, and which can guide him toward his peers so as to carry out, together, the ideal of peace and reason. Outside this path he will know only violence and inertia of command. I take social education the victory that we must achieve over our disgust of treating with justice and humanity those with whom we are placed in contact by everyday relations: domestics, workers, peasants. Finally, social education is the discipline we must impose on ourselves; the obligation that we should engage ourselves to participate in, be it directly or indirectly, for the creation and maintenance of works that seek to attenuate material or moral misery.

The writings and proposals of Indigenist thinkers, particularly of Price-Mars, Alexis, Bellegarde, make explicit the difficulties in overcoming the legacies of the colonial past. As I have said earlier, since the beginning of the construction of the Haitian nation, conflicts of interest became increasingly frequent and intense. After abolition and independence, the post-slavery elites (Mulattoes and/or Black) revealed themselves to be ever more hostile to the majority of the peasant, working, poor population. Analysing the authors of this Revue, we can infer that the political projects of the elites throughout history did not contemplate the social inclusion of the masses. Haitian elites showed no interest in creating opportunities for the majority of Black Haitian peasants, but rather to exploit them and the exclude them, leaving them to die in chronic misery. As Roumain (1944) observed in his novel Gouverneur de la rosée, most of the population continued to live in a condition of misery, permanent crises, illiteracy, lack of infrastructure in social means, ecological problems, disease, discrimination, and so forth. These elements were compounded by the sociopolitical instability caused by conflicts of interest 
of the most varied natures ("racial"; economic, cultural), which inhibited the construction of a political project that could include this exploited, marginalized mass of people. These factors made the dreams of the Indigenists seem distant, particularly for Jean Price-Mars, who had envisaged the construction of an indivisible nation (Ciarcia 2005:4). Michel Rolph Trouillot has magisterially synthesized the opposition between the Haitian State and the Haitian nation. According to him, the Haitian State has historically constituted itself in opposition to the nation, because it has always assumed a predatory relation to the people (Trouillot 1990). The Haitian State and its post-slavery elites have sought, and still seek, to maintain, at all costs, the social, economic and cultural structure, with the self-same characteristics of the past.

As the main thinker of Indigenism, the work of Jean Price-Mars occupies an important place in our discussion. Not only did he publish plenty, he also elaborated a specific view of the problems that Haitian society was facing during the United States Occupation. The author faced the problem by proposing that the Haitian elite rethink its way of acting, enabling the integration of the masses by modern life, recognizing and respecting African legacies. It is in this way that a Haitian identity premised on respect for and recognition of the other can be constructed. In what follows, I consider how the work of certain authors of the Revue Indigène, particularly Price-Mars, were interpreted by some of the thinkers ${ }^{11}$ of the Revue Les Griots.

\subsection{Writers of the Revue Les Griots in the Haitian crisis}

Many Indigenists agreed in the need to construct a Haitian identity based on a positive evaluation of culture originating in Africa. This is also true of the authors of the Revue Les Griots ${ }^{12}$. They admitted that the Haitian people result from a mixture of races from Africa and Europe. According to Viatte (1954: 452), the writers of Les Griots emphasized a set of elements that constitute the personal attributes of the Haitian man, of which seven are of African origin: "Super-human fanaticism; melancholy; mysticism; innate sense of ritual; heightened benevolence; compassion when faced with suffering; a naïve and unshakeable faith in God". On the other hand, they highlighted Latino elements that compose the Haitian personality: "a capacity for literary activity; a taste for discourse; invincible desire for the ideal; enthusiasm". The Griots thus saw the Haitian as being the convergence of two large branches. Charles (1984: 82) claims that the writers of the Revue Indigène sought to re-elaborate the Haitian mentality through the literary arts of the local culture. The Griots sought to bring about this reform through education, favouring the teaching of the history of Black Civilization, and Haitian literature, which was not then a part of the national curriculum, unlike French literature which was obligatory. As for the vodou religion, the Griots considered it to be a fundamental mark of Haitian identity, through which relations between Haitians and Africans could be established.

With the end of the United States Occupation of Haiti in 1934, the intellectuals of the Revue Les Griots revised the proposals of the authors of the Revue Indigène to, in their view, adapt them to the needs of the country. Tracing Haitian history, Denis and Duvalier (1948) present the class struggles that occurred in the country, noting that, along with the universal class struggle, Haiti was also the stage for race prejudice which had been instated by the colonizers to justify slavery, and had endured despite efforts at overcoming it. With the historical diagnosis of the writers of the Revue Les Griots, they proposed to take on the demands of the popular classes, setting themselves up as their representatives.

\footnotetext{
11 In 1967, Price-Mars positioned himself against the writers of the Revue Les Griots, qualifying their work as pseudo-scientific (Price-Mars 1967).

12 The Revue Les Griots was created in the 1930s, with some of its main representatives being Louis Diarquoi, Lorimé Denis, François Duvalier (Jean Pierre, 2009).
} 
Later, they developed the noiriste ${ }^{13}$ ideology, which can be understood as a simplification of the ideas of the writers of the Revue Indigène, keeping only the explicitly assumed idea that there existed a historical problem in Haitian society, which is that of skin colour, manifest as a conflict between Blacks and Mulattoes. Later, as they instrumentalized the matter of skin colour, Duvalier preached a sort of reverse racism as a solution. In his writings, Jean-Price Mars did not profess racism, nor did he propose a hierarchical solution to sociocultural conflicts. In order to show how to overcome the dualism between Black and Mulatto, Price-mars did not hesitate in taking his surname as a synthesis of these two ethnic categories, adopting a part of the surname of a Haitian Mulatto intellectual. His surname used to be simply "Mars", but he adopted "Price" from Hannibal Price, who was the son of an Englishman and a Haitian woman. That is how Jean Mars came to be Jean Price-Mars (Nicholls, 1975). According to Nicholls (1975), this symbolic gesture affirms Price-Mars desire to prove that the Haitian is the synthesis of two racial nuances. For him, Haitians (Mulattoes and Blacks) should come together not only to defend the Haitian nation, but also to fight the prejudicial and arbitrary hierarchies present in the country.

Reiterating their desire to construct a "Haitian identity", those who adhered to a noiriste ideology conveyed some concrete demands: to promote respect for the vodou religion; to value African culture (art, music, literature, history); restructure the educational system; and reduce the influence of the Roman Catholic Church in education. Through the noiriste ideology, exploring the contradictions between Black and Mulatto, Duvalier reclaimed the place of Blacks in political power, proposing to exclude the Mulatto elite which had, up until then, monopolized power. Nicholls $(1975: 653)$ states that:

Noiriste authors built a political theory based on their psychological, biological and social ideas. They argued that political power should be seized from the hands of a political elite, and that an alliance should be established between the growing Black middle class and the masses. They proceeded to study Haitian history, and perceived that political power was in large part monopolized by the Mulatto bourgeoisie, serving only the interests of the small class.

After a historical analysis of the concentration of political power in the hands of Mulattoes, Denis and Duvalier (1948), in Le problème des classes à travers l'histoire d'Haïti, concluded that Blacks should take power from them. Unlike Jean Price-Mars, who had been a defeated presidential candidate in 1930, Duvalier was elected president in 1957.

Duvalier was always in favour of the discriminated masses, and against the anti-vodou campaign. When he gained power, the vodou religion began to enjoy certain liberties. According to Jean Pierre (2009: 91), Duvalier allowed vodou rituals to take place freely, and his sympathy for the religion gained him favour among certain ougan. According to Corten (2001: 51-53), he claimed vodou for himself, saying that he was empowered by vodou spirits.

Through the noiriste ideology, the Duvalier regime replaced national and class identities by a pretence "racial identity", and put other forms of identity formation under his control. He established a totalitarian system, persecuting not only some members of the Mulatto elite, but also students, and forcing Black and Mulatto intellectuals and politicians into exile. Later, he waged a ferocious war against Communism. His regime not only subjugated peasants, but also prevented any form of opposition from emerging. To maintain his control, through an alliance with the United States, he created the Tonton Macoute militia ${ }^{14}$, also known

13 The adjective noiriste is composed of the noun noir (Black), and it is tied to noirisme, an ideology developed in Haiti during the first half of the 2oth Century. In the second half of that century it came to prominence, with François Duvalier as an emblematic figure.

14 A paramilitar group created by the dictator Fraçois Duvalier in 1959 under the name of the Milice Volontaires de la Sécurité Nationale (MVSN), commonly known by the name Tonton Macoute, or "Uncle Gunnysack”. They received direct orders from the dictators François Duvalier, 'Papa Doc', and later from his son and successor, Jean-Claude Duvalier, 'Baby Doc' (Diederich, 2005). 
as the Volontaires de la Sécurité Nationale. In Mémoires d'un leader du tiers monde, Duvalier writes that the Tonton Macoute had only one soul: Duvalier; that they knew only one chief: Duvalier; and that they fought for only one cause: to keep Duvalier in power (Duvalier 1969 in Hurbon 1987: 19).

According to Hurbon (1987: 20), with Duvalier in power, the political system he instated gradually undermined all ties of family solidarity. He writes that "you can be scared of a brother-in-law, a sister-in-law, a cousin, an uncle, etc; for no one knows who in one's family has a Tonton Macoute membership card". He further notes that all of the traditional association in the popular neighbourhoods, in the field, were affected by the power of the Tonton Macoute, who monopolized public and private goods, and who repressed whoever they wanted to, whenever they wanted to.

Along with political power, Duvalier and the Tonton Macoute had religious power. They appropriated the mysticism and witchcraft attributed to the vodou religion to disseminate fear in the population, reigning so completely over the people as to penetrate the collective imaginary. The Duvalier regime operated through systematic violence and repression. The policies he adopted became an obstacle for peasants, preventing them from living a dignified life (Hurbon 1987: 21-22). All of the proposals of the former Indigenist François Duvalier in favour of the masses were nothing but empty words. His time in power brought no benefits for the Black masses he claimed to represent. Through the noiriste ideology, Duvalier sought to replace the domination of the Mulatto elite with that of a purported "Black elite" - the Tonton Macoute.

The construction of a Haitian identity, according to the indigenists, must necessarily involve the recognition and promotion of Haitian culture, the Creole language, the Vodou religion and values of African origin. When François Duvalier reached power, the ideals of indigenism, though appropriated by him, were systematically ignored. The proposal for the construction of a Haitian identity that could overcome the internal binarisms, as suggested by Price-Mars, remained far from being achieved. If another demand of Duvalier before being elected was to decrease the power of the Catholic Church in Haitian education, during his long reign (1957-1971) it was found that much of the education continued to be provided by Frères de l'Instruction Chrétienne. There was hence no reduction of the influence of the Catholic Church.

Upon attaining power, Duvalier limited any sort of critique of his government. The acceptance of Crioule as an official language of the country, alongside French, would have to wait for the new Constitution on the $29^{\text {th }}$ of March 1987. It was also with the new Constitution that Haitians earned the right to organize themselves into associations, to express themselves publicly, and to form political parties (Hurbon 1987).

Theoretically and politically, the thought of the writers of the Revue Indigène had significant effects insofar as they offered paths to overcome the crisis of Haitian identity. In a society marked by multiple conflicts, the construction of a Haitian identity, according to Price-Mars, would be a suitable starting point for overcoming internal contradictions.

The fact that the Haitian elites did not want to give up their privileges enabled the radicalization of the political movement through the emergence of Les Griots. The election of Duvalier should have been an opportunity to implement policies that furthered the emancipation of the exploited, discriminated and marginalized masses. However, his government was characterized by a contradiction between ideology and political practice. Thus, Duvalier's noirisme, as it was manifested, was perhaps the most perfect expression of what Fanon called "double narcissism". In his analysis of the dramatic effects of European colonialism on people who lived under this system, Fanon asks us to consider that an understanding of the relations between Blacks and Whites must first tackle the double narcissism that, on the one hand, imprisons Whites in their whiteness, and, on the other, Blacks in their blackness. This process, the author argues, results in a vicious circle in which there are Whites who feel superior, and Blacks who want to show Whites the richness of their thought (Fanon 2008: 26-27). 
By defending noirisme, the representatives of this ideology were incapable of perceiving that the social problems that existed in Haitian society could not be solved by following a dualistic and hierarchical route. This, to a degree, barred the noiristes from understanding that they were part of the same oppressive, discriminatory and racist system. Overcoming social contradictions would thus demand of the noiristes that they stepped outside of their blackness, and that Mulattoes stepped outside of their purported whiteness. Their authoritarianism and elitism inhibited any possibility of dialogue to overcome the crisis in the country. Repression was the essence of this regime. An example of this is the assassination of the Socialist author Jacques Stephen Alexis, one of the critics of the pseudo-scientificism of the authors of Les Griots and the noiristes.

These observations on Indigenism are sufficient for us to realize that it was a complex, contradictory and rich movement. One may ask what we can gain by an article about an old artistic-political movement. Since it is a movement that is not often referenced by the critics of colonialism, and since the social, economic, cultural and political contradictions of their exponents endure into the present, I argue that we can gain a lot by establishing a dialogue with the writings of these authors. They can draw our attention to certain dangers that may crop up during contemporary crises, whether in Haiti or in other countries where the evils of colonialism and slavery continue to operate.

\section{Price-Mars's Indigenism and post-colonial debates on identity}

This article has a panoramic view of how certain intellectuals and politicians dealt with sociopolitical, cultural and economic crises in Haiti during the United States Occupation. I have drawn attention to the matter of identity, showing how it is always at the centre of a game of power. Without theorizing identity itself, as a final reflection, I have established connections between the works of the Indigenists and more contemporary debates on identity.

Although identity is a concept that has been amply discussed, particularly by the social sciences, it still raises debates of various sorts, concerned with explaining the position and affirmation of individuals as sociopolitical and cultural subjects in the social structures of which they are a part.

The conceptualization of identity changes in the same way that the idea itself of identity changes. Although, from the theoretical point of view, there may be elements in the sociocultural realities that can be used to construct types of social identity, the latter can only be apprehended through discourse and the analysis of representations. In Identités et cultures 2: Politiques des différences, Hall (2013: 22) stresses that identity is a narrative, a story; something constructed, enunciated, and not something that we find in a particular place. Concerning "Black identity", Hall claims that it has never been "at our disposal". It has always been an unstable identity on the political, cultural and psychic levels. Although Hall makes no explicit reference to slavery, I interpret him as saying that the violent exclusion of Blacks from the category of 'human being' by European colonizers precluded any sort of prolonged, positive self-affirmation.

Since the slave system was implemented in the American continent, an effective affirmation of Black people as subjects only occurred when Toussaint Louverture ${ }^{15}$ defeated the colonizers. Article 3 of the 1801 Constitution, which he promulgated, says: Il ne peut exister d'esclaves sur ce territoire, la servitude y est à jamais abolie. Tous les hommes y naissent, vivent et meurent libres et Français (There can be no slaves in this territory, servitude is abolished forever. All men born here live and die Free and French) (1801 Constitution in

\footnotetext{
15 The leader of the Haitian Revolution, François Dominique Toussaint Louverture, was born in Saint-Domingue on the $20^{\text {th }}$ of May 1743 and died on the $8^{\text {th }}$ of April 1803 in. the Prison of Fort de Joux, in France. He fought for the freedom of enslaved Blacks, and was defender of the equality of men. On the $29^{\text {th }}$ of August 1793, he declared: "Je suis dit-il, Toussaint Louverture. Mon nom s'est peut-être fait connaître jusqu'à vous. Jeveux que laliberté et l'égalité règnent à Saint-domingue. Je travaille à les faire exister. Unissez-vous à nous, frère et combattez avec nous pour la même cause”. During the prolonged fight for Independence, Toussaint Louverture led enslaved Africans to victory over the European colonizers, abolished slaver and assured the control of the colony by the natives in 1797, governing the island until the $25^{\text {th }}$ of August 1802, when he was kidnapped by the French (Périna 1997: 41).
} 
Joseph Janvier 1884: 9). Santo Domingo is thus conceived as the first country in modern times to have proposed not only a reflection on men, in all of their social, economic, and racial complexity, but also of the "big problem of the $20^{\text {th }}$ Century: the colonial problem" (Césaire,1960 in Périna, 1997: 37).

By approaching the matter of identity, Hall (1995: 10) offers three conceptions. The first corresponds to an individualistic conception of the subject. That is, identity is concentrated in one person. The subject that prevails in this conception is the Enlightenment subject, usually described as European and male, gifted with reason, conscience and action. The second conception is sociological. Here the identity is formed in the interaction between individual and society. In this conception, the subject possesses an interior self, that is his or her true self, but which is formed and modified in continuous dialogue with external cultural worlds and with the identities they offer. In this conception, identity bridged the interior and the exterior (articulating the public and private worlds) (Hall 1995: 11). In the sociological conception, identity is no longer something unified and fixed, as expected in the Enlightenment conception:

The subject, who previously had experienced a unified and stable identity, now becomes fragmented; composed not of one, but of many identities, some of them contradictory or unresolved. Concomitantly, the identities that composed the landscapes out there, and which ensured our subjective conformity to the objective necessities of culture, are being challenged as a result of a structural and institutional change. The process of identification itself, through which we Project ourselves in our cultural identities, has become more open, variable and problematic (Hall 1995: 11-12).

Analysing this notion of identity, it is evident that negotiation, change and flexibility have become the essence of modern identity. The post-modern subject follows from this. According to Hall, this is the third conception of identity. It thus came to be seen as a "moveable feast: continuously formed and transformed in relation to the manners by which we are represented and treated in the cultural systems that surround us" (Hall, 1995: 12). For the author, it is impossible to exist in a secure, stable, unified and coherent identity. Insofar as the systems of meaning and cultural representation are being multiplied, individuals come to be confronted by a diffuse, confused and fluid multiplicity of possible identities, and they can identify with all of them. Identity can be modified according to how the subject is treated or represented - which means that identification is no longer seen to be automatic, but something than can be gained or lost (Hall 1995: 18).

This flexibility of identity in the modern world is conceived to be a crisis of identity. That is, "identity only becomes an issue when it is in crisis, when something supposedly fixed, coherent and stable is shifted by the experience of doubt and uncertainty" (Mercer, 1990 apud Hall, 1995: 9).

As we have shown previously, during the first half of the $20^{\text {th }}$ Century in Haiti, a crisis made it possible for the United States, which had long had plans to (re)colonize Haiti, to finally occupy it. Haitian authors, in particular Jean Price-Mars, proposed a notion of identity as a broad category capable of subsuming the differences and diversities that existed in Haitian society. This proved necessary in order to overcome the internal binaries that had facilitated the United States Occupation of Haiti from 1915 to 1934. In Price-Mars's view, a (re)configuration of Haitian identity premised on dialogue and negotiation would enable the construction of a nation in which sociocultural and racial discrimination, as well as economic inequality, could be annihilated. Difference and diversity would not, therefore, be motives for exclusion, nor for discrimination, because this identity should be constructed from plurality. Even changing his name from Jean Mars to Jean Price-Mars is an example of his personal efforts at overcoming an essentialist identity.

However, the movement itself reveals that the power game, the struggle for maintaining privilege, led the economic and political elite to adopt a position in favour of the United States, which had established a violent occupation of the country, subjugating all citizens, including the elites that hosted them. It seems as if the structural dominance that exists in modern societies inhibits a space for dialogue not only between the 
dominated and the dominators, but also among the dominated - precisely because many of the dominated aim to occupy positions of domination, instead of fighting for the end of the colonialist logic of domination and exploitation. Through this domination, those who are in a dominant position seek to silence those that are dominated and, at the same time, to impose on them a representation which they find unfamiliar. This silencing is an act of violence, which makes the dominated a subject that appears to lack a voice. Such violence significantly affects how the identity of the dominated will be constructed, in as much as the dominated is not only denied as a bearer of rights, but also because his existence is monitored by both political acts and the discourses of the dominant. Yet this does not mean that those who are in the position of being dominated are passive, since they are always active in disputes to escape the position of being dominated.

The United States Occupation of Haiti tore open the contradictions of the country, making them clearly visible. It forced certain Haitian thinkers to question how social relations were constituted throughout the country's history, resulting in Haitian Indigenism, which was a movement of resistance and political and ideological negotiation, organized to combat the Occupation, and, at the same time, to (re)construct the Haitian nation. The movement was also important for proposing social theories, not only to solve the sociopolitical, cultural and economic conflicts of Haiti, but also to construct other multiracial, post-slavery and postcolonial societies. In this way, establishing a dialogue between Haitian Indigenism and other traditions of thought that seek to understand and overcome the evils of colonialism can enrich our understanding of the complexity of contemporary sociocultural relations.

Aiming to establish a relation with the post-colonial debate, relying on the synthesis of Sérgio Costa, I identify two founding elements in post-colonial thought: (i) overcoming the dualism or binary by nonhierarchical means within sociopolitical and cultural games; (ii) an interest in explaining the sociocultural traumatism of two sets of conscience, that of the (ex-)colonizer and of the (ex-)colonized (Costa 2006). In the same vein, Achille Mbembe (2006) provides various levels of critique that characterize post-colonial thought. In the first level, we find: (i) the heterogeneity of this thought; (ii) the unfolding of colonial violence inherent to a particular idea of reason; (iii) the projection of a humanité-à-venir, which overcomes the inhuman figure of colonialism and racial difference; (iv) deconstruction of the colonial prose, unmasking its power of falsification; (v) combating racism in general, and colonial racism in particular.

A second level of critique questions Western humanism and universalism, forging a path for a politique de semblable (a politics of the similar) and a recognition of the other and of difference as a goal. On a third level, post-colonial thought is constituted by enchevêtrement and concaténation (tangle and concatenation), which postulates identity as something that originates in multiplicity and dispersal. According to the author's analysis, the political force of post-colonial thought resides in the social and historical struggles of colonized societies, particularly their re-reading of the theoretical praxis of liberation movements. Although post-colonial thought is today the preserve of Anglo-Saxon academic institutions, and of intellectuals writing in English, it was inspired by French-speaking intellectuals and it would be significant to widen the debate to include authors from other subaltern regions.

Considering the importance of the above elements for post-colonial thought, and considering the specificities of Haiti (its Revolution, its intellectual debates on colonization, race, identity, sociocultural problems and internal politics, as well as its relation to the wider world), I ask whether the post-colonial debate would not have something to gain by look at Haitian intellectual output. Taking into account Jean Price-Mars's solution for the Haitian crisis in Ainsi parla l'oncle, his rejection of a hierarchical solution, his rejection of noirisme and the thought of Les Griots, his proposal for dialogue and negotiation, his suggestion that we reread the values of those who have traditionally occupied marginal or disadvantaged positions, and his efforts at questioning the values of the dominant - do all these things not make him a candidate for a precursor of post-colonial theory? What would be the effects of the thought of an intellectual like Jean Price-mars in 
the reflexive developments of the post-colonial critique? I cannot answer these questions here. However, since there is a hegemony not only of the production of knowledge, but also in the institutionalization of certain theoretical currents; and since coloniality functions in a total form, as Frantz Fanon recognized; and considering that the field of the academy or institutionalized practices, and relations of power, configure the production, circulation and consumption of knowledge - all of this should lead post-colonial authors to be more critical both of their own postures and the dialogues they establish, so as to avoid reproducing the subalternization and/or hegemonization of certain intellectual traditions.

One of the inspiring aspects of the Revue Indigène is the will, and the commitment, of Indigenist authors to find and establish dialogue with other intellectuals from subaltern regions, including Latin American countries, the French Antilles, etc. Normil Sylvain raises this point: "Nous sommes coupables d'ignorer l'Amérique Latine parce que les origines sont semblables et qu'un grand danger commun nous menace" (We are guilty of ignoring Latin America because the origins are similar, and this is a great danger that threatens us) (Sylvain, 1927: 6). Thus, by agreeing that the countries that suffered the effects of colonization share common problems and latent dangers, these authors understood that a consistent critique of colonization and its effects must integrate subaltern authors from various parts of the globe. Despite the language barrier, this is what the signatories of the Revue Indigène did when they proposed that Haitians read Latin American intellectuals, such as San Juana Inês de la Cruz, Amado Nervo, Alfonso Rey, from Mexico; Lugones Enrique Larrela, from Argentina; Monlalvo, an admirer of Garcia Moreno, from Ecuador; Ruben Dario, from Nicaragua; Gonçalves Dias, Castro Alves, Gonçalves Magalhães, Machado de Assis, Ruy Barbosa, from Brazil, and so forth (Sylvain, 1927: 7-8). This would not only enrich the social and literary thought of Haiti, but also allow us to better understand how the legacies of slavery and colonization operate. The advice of these intellectuals continues to be relevant today. By widening the horizons of dialogue, subaltern critiques will become more fruitful.

Received: September 25, 2019

Approved: February 25, 2020

Translated by: Luiz Costa 


\section{References}

ALEXIS, Stéphen. 1933. Le nègre masqué. Port-au-Prince: Fardin.

BELLEGARDE, Dantès. 1928. Pour une Haïti heureuse I. Port-au-Prince: Chéraquit. . 1929. Pour une Haïti heureuse II: Par l'éducation et le travail. Port-au-Prince: Chéraquit.

. 1937. La résistance haïtienne. L’occupation américaine d'Haïti: Récit d'histoire contemporaine. Montréal:

Les Éditions Beauchemin.

BYRON, Jhon Picard. 2014. «La pensée de Jean Price-Mars. Entre construction politique de la nation et affirmation de l'identité Culturelle haïtienne». In: Production du savoir et construction sociale. L'ethnologie en Haïti. Québec/ Port-au-Prince: Les Presses de l'Université Laval/ Les Éditions de l'Université d'État d'Haïti, pp : 47-80.

CHARLES, Judithe. 1984. L'Indigénisme dans le Roman Haïtien. Master's Dissertation. Université McGill. CIARCIA, Gaetano. 2005. "Jacques Roumain, OEuvres completes». Gradhiva, online 58(1): 261-263. Avaiable at: https://journals.openedition.org/gradhiva/403?lang=en. Accessed on: Jan 5, 2020.

CLORMÉUS, Lewis Ampidu. 2012. «La démonstration durkheimienne de Jean Price-Mars: faire du vodou haïtien une religion». Archives de Sciences Sociales des Religions. (159): 153-170. Avaiable at: https://journals.openedition.org/assr/24140. Accessed on: Jan 10, 2020.

COLBERT, Jean-Baptiste. 1685. Le code noir: Recueil d'édits, déclarations et arrêts concernant les esclaves nègres de l’Amérique. Paris: Chaz les Libraires Associez.

CORBISIER, Roland. 1967. "Prefácio”. In: Albert Memmi (org.), Retrato do Colonizado Precedido pelo Retrato do colonizador. Tradução de Roland Corbisier e Mariza Pinto Coelho. 2. ed. Rio de Janeiro: Paz e Terra, pp. 1-17.

CORTEN, André. 2001. Misère, religion et politique en Haïti: diabolisation et mal politique. Paris: Karthala. COSTA, Sérgio. 2006. "Desprovincializando a sociologia: a contribuição pós-colonial". Revista Brasileira de Ciências Sociais [online] 21(60): 117-134. Avaiable at: https://www.scielo.br/scielo.php?pid=So10269092006000100007\&script=sci_abstract\&tlng=pt. Accessed: Feb. 5, 2020.

DENIS, Lorimer; DUVALIER, François. 1948. Problème des Classes à Travers l'Histoire d'Haïti: sociologie politique. Port-au-Prince : Imp. de l'État.

DIEDERICH, Bernard. 2005. Papa Doc \& The Tontons Macoutes. Princeton: M. Wiener Publishers.

FANON, Frantz. 2008 [1952]. Pele negra máscaras brancas. Salvador: EDUFBA.

FARDIN, Dieudonné. 2009. Histoire de la littérature Haïtienne, tom.5. Épanouissement Du mouvement Indigéniste Haïtien. Tom.5. Port-au-Prince: Fardin.

FIRMIN, Antenor. 1885. De L'égalité des races humaines. Paris: Librairie Cotillon. GUERRIER, Pierre André. 2008. Pour une Haïti Moderne: Essai d’Actualité. Paris : Édition Le Manuscrit. HALL, Stuart. 2013. Identités et cultures 2: Politiques des différences. Paris: Éditions Amsterdam. . 1995. A Identidade cultural na Pós-modernidade. Tradução de Tomaz Tadeu da Silva \& Guacira Lope Louro. Rio de Janeiro: 11 ed. Editora DP\&A.

HECTOR, M; HURBON, L. 2009. Genèse de l'État Haïtien (1804-1859). Paris: La Maison des Sciences de l'Homme.

HURBON, L. 1987. Comprendre Haïti. Essai sur l'État, la nation, la culture. Paris: Les Éditions Karthala.

JEAN, Dieumettre. 2018. Identidade-relação e transculturação: uma leitura do romance Compère Général Soleil, de Jacques-Stéphen Alexis. Master's dissertation, Universidade Federal de São Paulo. Guarulhos.

JEAN PIERRE, Jean Gardy. 2009. Haiti, uma República de Vodu? Uma análise do lugar do vodu na sociedade haitiana à luz da Constituição de 1987 e do decreto de 2003, 2009. Master's dissertation.

Pontifícia Universidade Católica de São Paulo (PUC-SP), São Paulo. 
JONASSAINT, Jean. 2013. "Césaire et Haïti, des apports à évaluer». Francophonies d’Amérique, (3): 135-165. Avaiable at: https://www.erudit.org/en/journals/fa/2013-n36-fao1791/102938oar.pdf.

Accessed: Jan. 21, 2020.

MBEMBE, Achille. 2006. Qu'est-ce que la pensée postcoloniale? Entretient avec Achille Mbembe. Revue Esprit, 330(12): 117- 133. Avaiable at: https://esprit.presse.fr/article/achille-mbembe/qu-est-ce-que-lapensee-postcoloniale-entretien-13807. Accessed: Jan. 24, 2020.

NICHOLLS, David. 1975. «Idéologie et mouvements politiques en Haïti, 1915-1946». Annales. Économies, Sociétés, Civilisations, 30(4):654-679. Avaiable at:https:|/www.persee.fr/doc/ahess_0395-2649_1975_ num_30_4_293637 Accessed on: Jan 03, 2020.

PARISE, Normelia M. 2014. «Literatura e oralidade no Haiti: A poesia em Crioulo de Georges Castera". Revista Boitatá, 9(17): 72-87. Avaiable at: http://www.uel.br/revistas/uel/index.php/boitata/article/ view/31611 Accessed on: Jan 02, 2020.

PÉRINA, Mickaëlla. 1997. Citoyenneté et Sujétion aux Antilles francophones. Post-esclavage et aspiration démocratique. Paris: L'Harmattan.

PRICE, Hannibal. 2012 [1898] . De la Réhabilitation de la Race Noire par la République d'Haïti. Port-au-Prince : Les Editions Fardin.

PRICE-MARS, Jean. 1919. La Vocation de L’Élite. Port-au-Prince: Imprimerie Edmodnu Chenet. . 1928. Ainsi Parla l'Oncle: Essais d'Ethnographie. New York: Parapsychology Foundation Inc. . 1929. Une Étape de l'Évolution Haïtienne Étude de Socio-psychologie. Port-au-Prince: Imprimerie La Presse. . 1956. Formation ethnique folk-lore et culture du peuple haïtien. Port-au-Prince, Haïti: Imprimerie N.A. Theodore. . 1967. Lettre ouverte au Dr. René Piquion, directeur de l'Ecole normale supérieure, sur son "Manuel de la négritude": Le préjugé de couleur est-il la question sociale?. Port-au-Prince: Éditions des Antilles. ROUMAIN, J. 1944. Gouverneur de la rosée: Roman. Port-au-Prince, Haïti: Impr. de l'État. SOUFFRANT, Claude (org). 1991. Littérature et société en Haïti. Port-au-Prince, Éditions Henri Deschamps.

ST-JOHN, Spence. 1886. Haïti: ou, La république noire. Paris : E. Plon, Nourrit et Cie.

SYLVAIN, G. Normil. 1927. «Chronique/ Programme». Port-au-Prince : La Revue Indigène: les arts et la vie, 1(1). TROUILLOT, M.-R. 1990. Haiti, state against nation: the origins and legacy of Duvalierism. New York: Monthly Review.

VIATTE, Auguste. 1954. Histoire littéraire de l'Amérique française, des origines à 1950. Québec, Presses universitaires Laval.

Frantz Rousseau Déus

PhD candidate in sociology, Institute of Philosophy and Human Sciences, University of Campinas. CNPq scholarship student. https://orcid.org/oooo-0002-3073-3796

Email: frantzrousseaudeus@yahoo.fr 